\title{
TEST FOR ALTERNATIVE INDICATOR OF SOYBEAN SOWING DEPTH
}

\author{
Doi:http://dx.doi.org/10.1590/1809-4430-Eng.Agric.v35n1p 128-133/2015
}

\section{NÁTALI M. SOUZA ${ }^{1}$, PEDRO H. WEIRICH NETO ${ }^{2}$}

\begin{abstract}
Among studies focused on increasing soybean grain yield, the ones related to sowing process are the most significant. Considering that soybean has an epigeal emergence, it becomes difficult to hint at the length covered by hypocotyl up to soil surface, or the actual planting depth. This study aimed to find an indicator that allows the identification of an ideal soybean planting depth. For this purpose, two complementary assays has been carried out in a greenhouse. The first aimed to identify structure s that could be indicators of seed planting depth, on a medium-textured soil from Campos Gerais region, in the state of Paraná, Brazil. Spring NK 8350 cultivar seeds were sown at five theoretical depths $(1,2,3,4$ and $5 \mathrm{~cm})$. As seedlings emerged, the "differentiation zone" and the "root curve" depths were measured. The second assay was the validation of the suggested indicators in assay 1 from two soils, one medium-textured and one clay-textured. For this assay, it was used BRS 232. Both the methodologies showed high correlation with the theoretical planting depth. Although their correlation coefficient values were close, the differentiation zone appeared to be the most efficient reference with less planting depth overestimation.
\end{abstract}

KEYWORDS: Glycine max L., planting process, root

\section{TESTE DE POSSÍ VEL INDICADOR DE PROFUNDIDADE DE SEMEADURA PARA A SOJA}

RESUMO: Dentre os estudos que visam a incrementar os rendimentos da cultura da soja, podem-se destacar aqueles relacionados ao processo de semeadura. Devido ao fato de a soja apresentar emergência epígea, torna-se difícil determinar a profundidade real de semeadura. O objetivo deste trabalho foi identificar indicador que possibilite a mensuração da profundidade de deposição de sementes de soja. Foram realizados dois ensaios em casa de vegetação. $O$ ensaio 1 visou a identificar possíveis estruturas indicativas da profundidade de semeadura, em um solo de textura média, característico da região dos Campos Gerais, no Estado do Paraná, Brasil. As sementes da cultivar Spring NK 8350 foram depositadas em cinco profundidades teóricas $(1 ; 2 ; 3 ; 4$ e $5 \mathrm{~cm})$. Após a emergência das plântulas, foram determinadas a profundidade da zona de diferenciação e a profundidade da curva na raiz. O ensaio 2 consistiu na validação dos indicadores sugeridos no ensaio 1, em dois tipos de solo, um de textura média e outro de textura argilosa. A cultivar utilizada no ensaio 2 foi a BRS 232. As duas metodologias mostraram alta correlação com a profundidade teórica de deposição. Embora tenham apresentado coeficientes de correlação próximos, a zona de diferenciação foi a referência mais eficiente, com menor grau de superestimativa da profundidade de semeadura.

PALAVRAS-CHAVE: Glycine max L., processo de semeadura, raiz.

\section{INTRODUCTION}

Soybean production is highly important for Brazilian economy. The national production in 2009/ 2010 was about 26\% of the world soybean production (UNITED STATE DEPARTMENT OF AGRICULTURE/USDA, 2011).

\footnotetext{
${ }^{1}$ Eng $^{\mathrm{a}}$ Agrônoma, Doutoranda, Bolsista Capes, Universidade Estadual de Londrina/Londrina - PR, Fone: (42) 3220-3092, natali.maidl@ gmail.com.

${ }^{2}$ Eng $^{\circ}$ A grícola, Prof. Doutor, Laboratório de Mecanização A grícola, Universidade Estadual de Ponta Grossa/Ponta Grossa - PR, lama1@uepg.br. 
In Brazil, the Campos Gerais region in the state of Paraná is a major contributor and a pioneer in adopting new technologies such as no-tillage system. Soybeans are one of the main choices for summer cash crops in this region followed by corn and dry beans.

Considering the three pillars of the no-tillage system - soil cover maintenance, minimum soil disturbance and crop rotation - it can be said that this system promotes significant changes in physical, biological and chemical soil properties. Planting has been the stage in which the grain production is most affected by those changes.

Therefore, planting process has a major role in the plant development, as it is responsible for crop implementation through adequate vertical - at proper, uniform depths - and horizontal distribution of seeds and fertilizers. This promotes appropriate conditions for germination, uniform emergence and crop development.

Depth is a variable commonly measured in studies about planting process quality and planter performance during crop implementation. This variable is usually empirically determined using complex, laborious, and scientifically unverified methods. ARATANI et al. (2006) and KOAKOSKI et al. (2007) evaluated the performance of soybean planters using seed planting depth measurements by carefully digging the grooves left on the soil by the planter until seeds were found, and then measuring the actual depth. Nevertheless, in spite of qualifying the planting process, other papers have not measured this variable (DIAS et al., 2009; MODOLO et al., 2008; TOURINO et al., 2009).

In soybean emergence, as well as many other plant species, the aerial part is withdrawn from the ground enclosed by cotyledons. Such mechanism is based on a fast and vigorous initial growth of the hypocotyl/ root axis, while the epicotyl and the primary leaves - which are inside the cotyledons - show almost no growth. According to CARDOSO (2008), this is called epigeal growth. Thus, it becomes complicated to determine the actual length covered by hypocotyl until it reaches soil surface, which would be the actual seed deposition depth.

Relevant studies on soybean seedling growth and emergence do not show clearly the hypocotyl length. BURRIS \& FEHR (1971) have studied ten growth methods to determine the most efficient one for evaluating soybean hypocotyl length. They reported that sand methods are not efficient when direct hypocotyl measurements are desired, but do not show how to measure this structure in this condition. VANZOLINI et al. (2007) have used a seedling length test by evaluating physiological quality of soybeans seeds; however, they have not shown how to measure it. KNITTLE \& BURRIS (1979) made a field study on soybean seedling emergence, using hypocotyl design without showing the evaluated structured.

With all that in mind, the objective of this paper is to suggest a method to measure planting depth for soybean seeds, aiming to facilitate the use of such variable in planting process studies.

\section{MATERIAL AND METHODS}

Two complementary assays were carried out in a greenhouse from August 2006 to July 2007. The first assay (Assay 1) consisted of a preliminary study to identify measurements to indicate planting depth. The second assay (Assay 2) was a validation test of the methods suggested after Assay 1 completion using soils of different textures.

Both assays were carried out under a completely randomized experimental design, and statistical analyses included a polynomial regression to adjust an equation, considering as independent and dependent variables the theoretical depth and the suggested indicators of planting depth, respectively. This analys is aims to represent mathematically the phenomenon and possible extrapolation of this behavior. Additionally, it was performed a correlation analysis between theoretical depth and suggested indicators of planting depth, aiming to estimate errors of the suggested ind icators. 


\section{Assay 1 - Preliminary determination of planting depth indicators}

It was used cylindrical pots of $0.10 \mathrm{~m}$ diameter, $0.13 \mathrm{~m}$ height with about $1 \mathrm{~kg}$ soil capacity. A medium-textured soil containing $240 \mathrm{~g} \mathrm{~kg}^{-1}$ clay, $96 \mathrm{~g} \mathrm{~kg}^{-1}$, and $664 \mathrm{~g} \mathrm{~kg}^{-1}$ sand was used to fill in the pots.

Seeds of the cultivar Spring NK 8350 (Syngenta Seeds, registered trademark) were planted at five theoretical depths $-1,2,3,4$ and $5 \mathrm{~cm}$, with five replications (5 pots per depth), and three seeds per pot. Planting was manually done and seed hilum was placed to the pot side, keeping the same distance between seeds and pot side. Soil compaction and moisture levels were the same for all pots. This assay was repeated three times.

Five days after emergence, seedlings were cut at the ground level, observed and compared to identify possible indicators that could help to determine the planting depth. The differentiation zone and the root curve depths were measured with a metric ruler. The first is the length between differentiation zone (a transition between root and aerial part) and soil surface. The latter is the length between a particular curve in root - a trait observed in normal seedlings - and soil surface (see Figure 1).

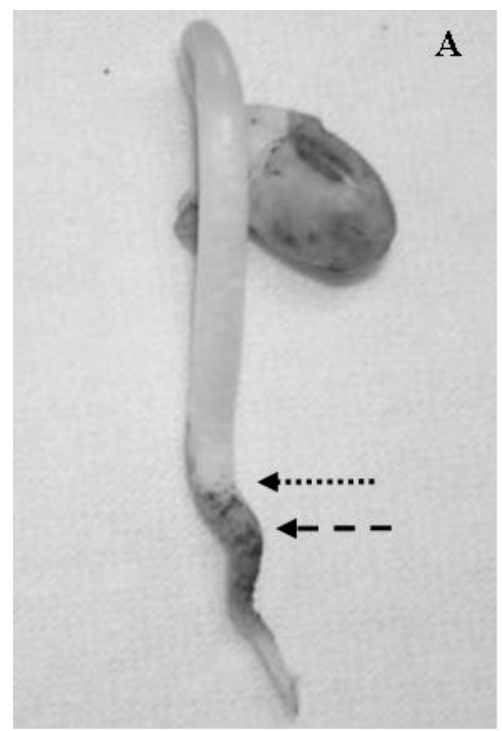

Differentiation zone
B

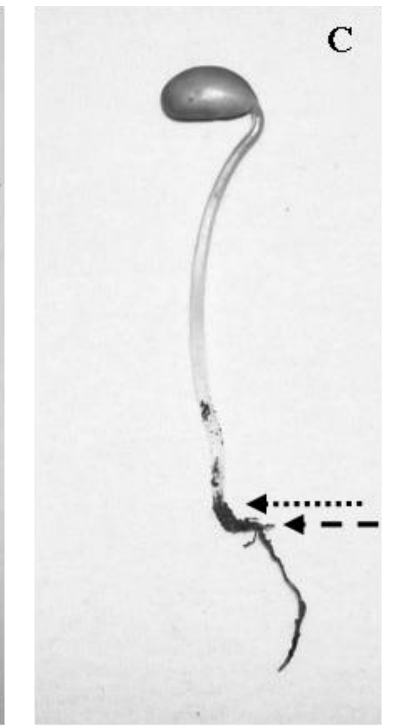

Root curve

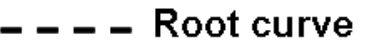

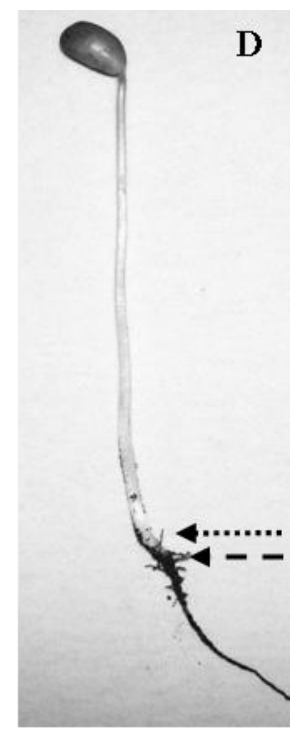

D

FIGURE 1. Measurement references. A) Five days after planting; B) Six days after planting; C) Seven days after planting; D) Eight days after planting

\section{Assay 2 - Indicators' validation in soils with different textures}

Experimental procedures applied in this assay were similar to those described in the previous one (Assay 1). However, in this study, it was used two soils with different textures. One had the same medium-textured as used in Assay 1 (240 g kg-1 clay, $96 \mathrm{~g} \mathrm{~kg}^{-1}$ silt, and $664 \mathrm{~g} \mathrm{~kg}^{-1}$ sand), and the other was a clay-textured soil (560 $\mathrm{g} \mathrm{kg}^{-1}$ clay, $110 \mathrm{~g} \mathrm{~kg}^{-1}$ silt, and $330 \mathrm{~g} \mathrm{~kg}^{-1}$ sand). Moreover, this assay has used seeds of the cultivar BRS 232 (Embrapa, registered trademark).

Five days after seedling emergence, differentiation zone and root curve depths were measured with a metric ruler.

\section{RESULTS AND DISCUSSION}

\section{Assay 1 - Preliminary determination of planting depth indicators}

Two characteristics were selected as indicators: differentiation zone and root curve depths (as described in the Material and Methods). The indicators' name are not related to any morphogenic 
activity; in the case of "differentiation zone", it is simply referring to the transition between aerial and root area, and does not allude to any kind of meristematic activity in the area.

The correlation coefficient (r) of "differentiation zone" and "root curve" depths with the theoretical depth were 0.9856 and 0.9796 , respectively. Data behavior acquired from both variables is displayed on Figure 2, using regression analysis and coefficients of determination $\left(\mathrm{R}^{2}\right)$ and comparing to the standard curve.

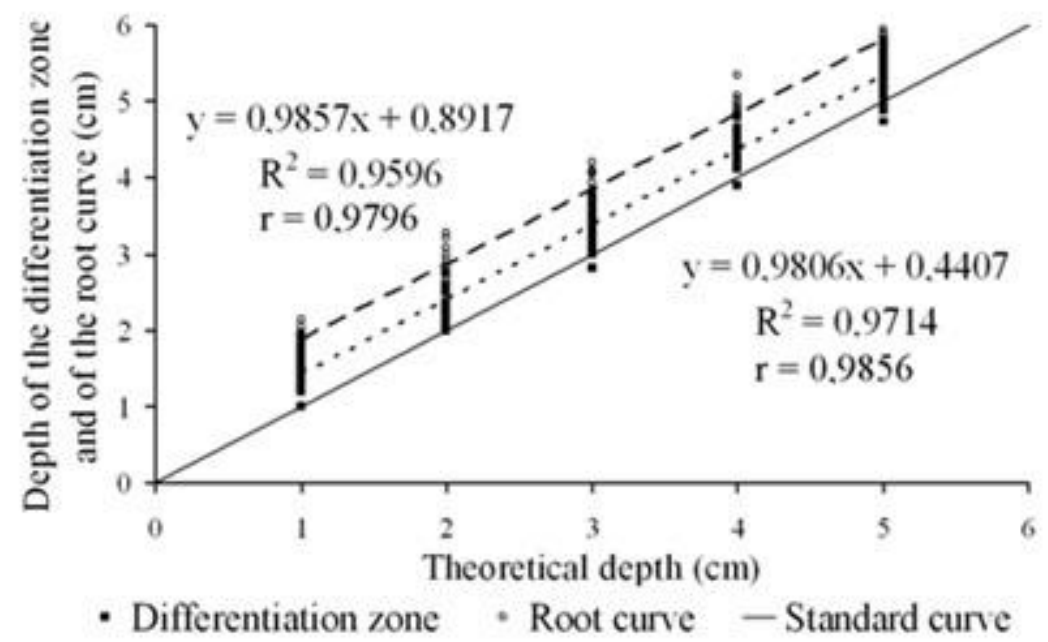

FIGURE 2. "Differentiation zone" and "root curve" indicators compared with a standard curve for a medium-textured soil.

MARCOS FILHO (2005) reported that embryonic axis development is partially controlled by auxins. These hormones are produced in the apical root meristem, and move through cortex cells to the growth area (basal area), inhibiting cell growth in one of the root side and making the root to curve towards the ground. This fact indicates that structures considered as indicators of planting depth are the result of such process, and therefore, it is noteworthy to use them as reference, as it was confirmed by the regression analysis.

\section{Assay 2 - Indicators' validation in soils with different textures} soils.

Indicators suggested in Assay 1 have proved to be significantly interesting on Assay 2 in both

Regarding to the medium-textured soil, the correlation coefficient between the "differentiation zone" and the theoretical planting depth was 0.9962 , and the correlation coefficient between the "root curve" and the theoretical planting depth was 0.9936 (see Figure 3 a).

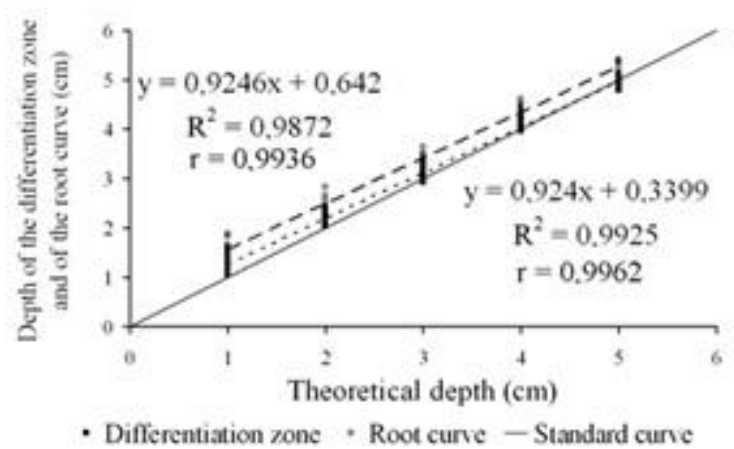

(a)

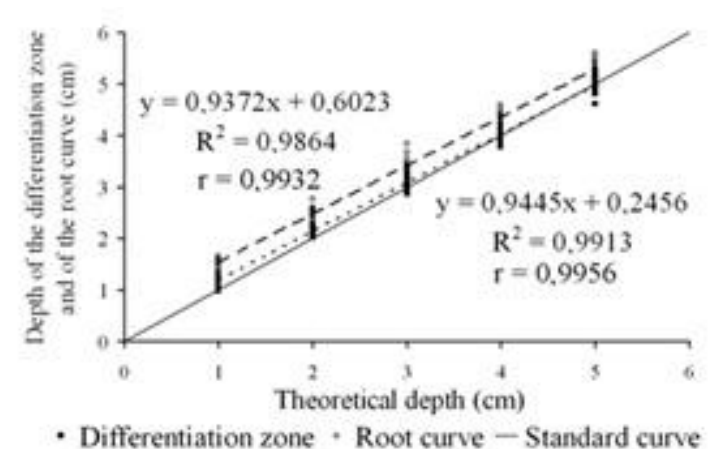

(b)

FIGURE 3. "Differentiation zone" and "root curve" indicators compared with a standard curve for medium-textured soil (a) and clay-textured soil (b) 
For the clay-textured soil, the correlation coefficient between the "differentiation zone" and the theoretical planting depth was 0.9956 , and the correlation coefficient between the "root curve" and the theoretical planting depth 0.9932 (see Figure 3 b).

Figure 3 displays the regression analysis and the determination coefficient $\left(\mathrm{R}^{2}\right)$ for data from both variables compared to a standard curve in both soil textures.

Comparing both the indicators, "differentiation zone" shows a more interesting performance, once the curve generated by this variable lies closer to the standard curve for both soil textures. Another relevant observation would be both method behaviors in relation to the depth; the curves for both variables lies closer to the standard curve as deposition depth increases. In this case, it assumed that seedlings do not change a lot, or at all in deeper depths as the larger mass of soil keeps them at the depth where their seed was placed.

With respect to the utilization of these indicators, it can be asserted that both are simple in execution. Moreover, the observations from preliminary assays showed that measurements demanded less effort when the seedlings were manipulated in the first few days after emergence. This is probably due to ease of removing the seedlings from soil in the initial development stages, when there is less lateral root growth.

\section{CONCLUSIONS}

Although both suggested indicators have shown high and very close correlation coefficients, the "differentiation zone" - or the length between the root/ aerial part transition area and the soil surface - appears to be a more efficient indicator of planting depth than the "root curve", as it presented a lower overestimation of the theoretical depths.

\section{ACKNOWLEDGEMENTS}

The authors thank the Programa Institucional de Bolsas de Iniciação Científica (Scholarship Program for Scientific Initiation) for the financial support provided for this study.

\section{REFERENCES}

ARATANI, R.G.; MARIA, I.C.; CASTRO, O.M.; PECHE FILHO, A.; DUARTE, A.P.; KANTHACK, R.A.D. Desempenho de semeadoras-adubadoras de soja em Latossolo Vermelho muito argiloso com palha intacta de milho. Revista Brasileira de Engenharia Agrícola e Ambiental, Campina Grande, v. 10, p. 517-522, 2006.

BURRIS, J.S.; FEHR, W.R. Methods for evaluation of soybean hypocotyl length. Crop Science, Madison, v. 11, n.1, p. 116-117, 1971.

CARDOSO, V. J.M. Germinação. In: KERBAUY, G.B. Fisiologia vegetal. Rio de Janeiro: Guanabara Koogan, 2008. cap. 20, p. 384-408.

DIAS, V.O.; ALONÇO, A.S.; BAUMHARDT, U.B.; BONOTTO, G.J. Distribuição de sementes de milho e soja em função da velocidade e densidade de semeadura. Ciência Rural, Santa Maria, v. 39, n. 6, p. 1721-1728, 2009.

KNITTLE, K. H.; BURRIS, J. S. Soybean hypocotyls growth under field conditions. Crop Science, Madison, v. 19, n. 1, p. 37-41, 1979.

KOAKOSKI, A.; SOUZA, C.M.A.; RAFULL, L.Z.L.; SOUZA, L.C.F.; REIS, E.F. Desempenho de semeadora-adubadora utilizando-se dois mecanismos rompedores e três pressões da roda compactadora. Pesquisa Agropecuária Brasileira, Brasília, v. 42, n. 5, p. 725-731, 2007.

MARCOS FILHO, J. Fisiologia de sementes de plantas cultivadas. Piracicaba: Fealq, 2005. 495 p. 
MODOLO, A.J.; FERNANDES, H.C.; SCHAEFER, C.E.G.; SILVEIRA, J.C.M. Efeito da compactação do solo sobre a emergência de plântulas de soja em sistema plantio direto. Ciência e Agrotecnologia, Lavras, v. 32, n. 4, p. 1259-1265, 2008.

TOURINO, M.C.C.; REZENDE, P.M.; SILVA, L.A.; ALMEIDA, L.G.P. Semeadoras-adubadoras em semeadura convencional de soja. Ciência Rural, Santa Maria, v. 39, n. 1, p. 241-245, 2009.

UNITED STATES DEPARTMENT OF AGRICULTURE/USDA. Table 11 Soybean Area, Yield, and Production. Disponível em: http://www.usd abrazil.org.br/home/reports.asp. Acesso em: 11 maio 2011.

VANZOLINI, S.; ARAKI, C.A.S.; SILVA, A.C.T.M.; NAKAGAWA, J. Teste de comprimento de plântulas na avaliação da qualidade fisiológica de sementes de soja. Revista Brasileira de Sementes, Viçosa, MG, v. 29, n. 2, p. 90-96, 2007. 